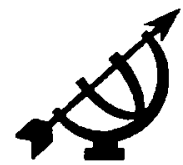

\section{The role and future of traditional leaders in South Africa}

\author{
Traditional Authorities Research Group ${ }^{1}$ \\ Contact person: Willemien du Plessis \\ Faculty of Law \\ Potchefstroom University for Christian Higher Education \\ POTCHEFSTROOM \\ E-mail: rmrwdp@puknet.puk.ac.za
}

\section{Abstract \\ The role and future of traditional leaders in South Atrica}

Traditional authorities play an important role in South Africa. Not everyone is, however, prepared to recognise them as role players. In government circles, on the one hand, a tendency exists to marginalise the role of traditional leaders and, on the other hand, a White Paper process is under way to spell out the role of traditional leaders in the future dispensation. Traditional authorities are seen by their communities as leaders through and by the people. In some instances it is even stated that they receive their authority from God. Research done in the Province of the North West, the Northern Province and the Province of KwaZuluNatal illustrates that in many of the communities in which traditional leaders serve they are regarded as leaders and they are also seen as symbols of unity in the community. The idea that the system of traditional leadership may be abolished was met by fierce resistance. Traditional leaders are recognised in terms of section 211 of the 1996 Constitution. The Constitution also recognises the possibility that national and provincial legislation may provide a role for traditional leaders at national, provincial and local level. Some of the findings of the above-mentioned research programme illustrate that traditional leaders were used as political tools in the past and that they should refrain from participating in party politics. Findings also highlighted the fact that the fragmented legislation dealing with the recognition and functions of iraditional leaders (caused by the apartheid system) should be rationalised. Some confusion still exists as to the role of traditional

1 All the members of the Traditional Authorities Research Group are regarded as co-authors of this article (see p. 324). A detailed list of all the members who contributed to the research underlying this article is published at the end of this article. The article in its present form was compiled by W, du Plessis. 
leaders vis-á-vis local government and it is recommended that the respective roles should be clearly spelled out. Traditional communities resent interference in their own affairs without them being consulted. In some respects rural women felt that they are not part of the decision-making process and that in some instances they are not allocated land. They, however, express the need to be consulted before any changes to their position is made. Traditional leaders have an important role to play in development at grassroots level. Traditional communities themselves need to be consulted when development is planned and a proper mechanism should be implemented to ensure that rural communities also benefit from rural development schemes.

Every person has a claim to those economical, social and cultural rights indispensable for his dignity and the free development of his personality (Van der Vyver, 1975:36 translation: WdP).

\section{Introduction}

In 1993 South Africa entered a new constitutional dispensation based on democracy, equality, fundamental rights, the promotion of national unity and reconstruction. The role of traditional leaders was dealt with substantially in the 1993 Constitution (s 181-183, Principle XIII, Constitution of the Republic of South Africa 200 of 1993; cf. also TARG, 1996i). A minimalistic approach was, however, followed in the 1996 Constitution (s 211 and 212 Constitution of the Republic of South Africa 108 of 1996). Within the new constitutional context, the role of traditional authorities and their communities should be redefined and/or adjusted.

The White Paper on Local Government (RSA, 1998) stated that a White Paper process on traditional affairs is underway. Certain issues have to be addressed dealing inter alia with the structure and role of traditional leadership and institutions, the principles relating to remuneration, a national audit of traditional leaders, the role of women, the role of traditional leaders in politics, the future role of the Houses and the Council of Traditional Leaders and the rationalisation of current legislation dealing with traditional leadership and institutions.

During 1995 a study² (TARG, 1996a; TARG, 19961; TARG, 1996m; TARG, 1996n) on the administrative and legal position of traditional authorities in South

2 This was also the premise from which the research undertaken by the Traditional Authorities Research Group (TARG) has been conducted and the findings and recommendations formulated. TARG was an independent research group which did not support any specific political or other viewpoint. The findings are based on objective research and on a penusal of national (and international) literature and legislation as well as on empirical research by means of discussion with communities, traditional leaders, government officials, NGOs and interest groups 
Africa and their contribution to the implementation of the Reconstruction and Development Programme was undertaken in three provinces, namely the Northern Province, KwaZulu-Natal and the Province of the North West. ${ }^{3}$ The research was based on literature as well as on fieldwork (TARG, 1996c; TARG, 1996 e $)^{4}$ undertaken in the Northern and North West provinces. Due to political unrest during the research period no fieldwork could be undertaken in KwaZuluNatal (TARG, 1996d).

In the light of renewed interest in traditional authorities and the White Paper process, the purpose of this article is to provide information and to give some perspective on the position of traditional authorities in South Africa, to make recommendations that may be used in the White Paper process and to contribute to the academic discussion on traditional authorities in general. General observations made during the research process will firstly be given, 5 then commonalities and similarities between the position of different traditional authorities in the various provinces will be indicated. The most important conclusions regarding the socio-political history, the legal position and development management will thereafter be discussed.

\section{General observations}

The following general observations were made during fieldwork and other research programmes undertaken in the Northern, the North West and KwaZuluNatal provinces. (These observations can be regarded as the basis on which the findings and recommendations for the three provinces were formulated.)

Traditional authorities are still recognised and respected by the different traditional communities interviewed. The idea of the abolishment of the institution of traditional authorities was received with resistance and it was mentioned by the communities interviewed that such a step will lead to chaos. The traditional leader is seen as one who is kgosi ke kgosi ka batho ("a chief is a chief through his people") and he has a definite role to play in traditional

3 Cf. footnote 2

4 In the North West 10 communities of the 72 officially recognised traditional communities were visited. The communities were identified by the House of Traditional Leaders North West and was regarded by them as being representative of the communities in North West. The sample included poor and rich communities. A pitso (meeting) was called and questions were put to the community as a whole. In the Northern Province individual interviews were held with traditional leaders and community leaders

5 These observations were later confirmed by traditional authorities and members of their communities as well as other stakeholders attending a conference on "Traditional authorities role and future" held at the Human Sciences Research Council on 18 July 1996 (cf. TARG, 1996j). 
communities. He or she is seen by many people as the embodiment of law and order, the upholder of values and as a provider for the needs of the community and, in some instances, even as an institution created by God. This idea was mentioned by men, women and youth members present during the research interviews conducted.

In principle traditional leaders should not be drawn into party politics and their role should remain one of neutral leadership. In all the communities interviewed, intervention by government through legislation drafted by people who have no insight into traditional values and customs, is resented. The principle of participation and consultation before legislation is drafted or passed, is therefore included in these proposals. The general feeling of the communities interviewed was that both the traditional leader and his or her community (and not only the traditional leader) should be consulted.

Traditional leaders have a definite role to play at national, provincial and local levels of government. At national and provincial levels they should be more involved in the formulation and decision-making process regarding policy and planning. At local level their function is to see to the proper implementation of policy and planning, especially regarding development in their relevant areas. In district or rural councils where more than two traditional authorities are present, forums should be established to assist with the formulation of policy, decisionmaking and planning at local level. Another opinion was that since the rendering of services is the function of local government, traditional authorities are not to be involved in the actual implementation of development projects. The traditional authorities and their communities are, however, to be consulted in this regard.

The principle that government should be brought closer to the people at grassroots level is also included in the proposal. Traditional authorities are seen in their communities as the institutional form of government closest to the people. It is apparent from the research undertaken that traditional leaders have a definite role to play in policy and the financing of development, especially in the rural areas. Traditional leaders cannot be ignored in either the formulation of policy, decision-making, planning or the implementation of policy by local government structures (RSA, 1998:4.3).

Research in various jurisdictions (Africa, Asia and South America) has indicated that in instances where traditional authorities were abolished by government or their sphere of jurisdiction interfered with by government, the desired effect was not achieved. Notwithstanding such intervention, traditional authorities have continued to exist. It would be wise to recognise this if the rural areas of South Africa are to be governed in peace and stability. It is therefore preferable for traditional authorities to be included, and to be given a definite and constructive role. Whatever the drawbacks, many people within the communities interviewed 
(see above) appear to remain deeply attached to the institution of traditional authorities (more than to the individual office holder as such). (Cf. TARG, 1996b:125-165.)

Empirical research and available data indicate that existing weaknesses of traditional authorities mainly relate to the following aspects (cf. TARG, 1996h):

- the tendency of traditional authorities to be autocratic and the lack of real leadership (qualities and actions);

- the fact that traditional leaders are born as chiefs and therefore often take power for granted, not realising the extent of their responsibilities as leaders;

- the lack of resources (including human, training, financial, infrastructural and physical resources) to perform their functions effectively and efficiently;

- an apparent inability to take responsibility for and to actively become involved in the development process;

- the fact that there is no structured policy for development by traditional authorities or for traditional authority areas;

- the politicisation of the institution of traditional authorities, as well as a lack of management activities in the process of policy implementation where such policy exists;

- the inability of traditional leaders to appropriately manage land use and natural resources in traditional authority areas;

- the lack of financial management skills, mechanisms and procedures;

- the absence of financial control as part of traditional authority administration; and

- the absence of a uniform application of a system of fines and levies.

An analysis of factors often tending to impact negatively on traditional authorities and the management of development, reveals that the following threats will have to be addressed as part of any strategy aimed at enabling traditional authorities to successfully fulfil their role (as described above) in respect of development.

- The negative perception of traditional authorities as being undemocratic (not having been elected) and therefore often regarded as outdated, especially among some youth organisations, has to be put into perspective.

- Traditional authorities are stigmatised as a product of previous government policies. 
- The attitude of (some) government officials implies that there is no role for traditional authorities in a democratic South Africa. ${ }^{6}$

- The efforts of provincial government (in the North West) to introduce a bill aimed at abolishing important functions of traditional authorities in the province during 1995, did not help to eradicate these fears. The Local Government: Municipalities Structures Act 117 of 1998 endows the MEC with the competence to decide on which functions a traditional authority may have.

- The apparent power and ability of government to amend custom and tradition by legislation and by invoking provisions of the 1996 Constitution, is experienced as another threat.

- The potential misuse by big business and private sector role players of rural investment, and opportunities which may result in financial loss and loss of rural land at the expense of rural communities, cannot be ignored.

- The lack of visible and tangible development activities in traditional authority areas, however, led to the conclusion that traditional authorities could not act as development managers.

The existence of such weaknesses, as mentioned above, in the very fabric of traditional authorities, as well as the possibility of the institution of traditional authorities being threatened by these weaknesses, is indicative of the type of legislative framework needed to strengthen and develop the institution of traditional authorities within the context of the 1996 Constitution. These strengths include the following aspects:

- The traditional leaders' religious standing and existence as part of a culture in which religion is not clearly distinct from law and social practices to which communities adhere.

- The fact that traditional leaders are often regarded as a creation of "God" traditional leaders being an integrated part of a culture which defines the values and norms of communities and form the basis of the existence of traditional communities.

- Traditional authorities have been in existence since time immemorial in terms of and as part of custom. 
- In many parts of the three provinces traditional authorities are afforded a certain degree of loyalty.

- Traditional authorities have been recognised as dispute resolution institutions used effectively at community level where social problems and problems relating to family matters are resolved without reference to Western type institutions (RSA, 1998:4.2).

- Traditional authorities have a certain undisputed amount of power (based on their standing in the concerned community) which can be used, inter alia, to implement policy, provided that the other requirements for successful implementation of such a policy are present.

- In many communities traditional authorities constitute the only authoritative structure known to communities in rural areas.

- Traditional authorities form, by their very nature and existence, an important link which can be used by government in introducing training and educational programmes in nural areas (e.g. agricultural development).

- Traditional authorities can also serve as a catalyst between government and ordinary people with the ability to ensure communication and dissemination of information on services provided by, for example, local government.

- Traditional authorities are the "trustee sui generis" of all land belonging to various traditional communities in terms of customary law.

- Traditional authorities are well positioned for the collecting of taxes, fines, levies and fees and could be used as agents to collect taxes for and on behalf of local, provincial and central government without government having to spend large sums of money to create new agencies for collecting levies and taxes at the risk of these newly established agencies not being favoured by rural communities.

- Traditional authority offices constitute administration centres in remote parts of the country and provide a base for the development of an improved rural administrative and development management network.

A host of opportunities exists for both government and traditional authorities themselves, which, if utilised to its full potential, could result in the successful implementation of development policies and laws in traditional rural authority areas. These include the ability to facilitate and co-ordinate the implementation of policies such as the Growth and Development Strategy in rural areas; to act as a link between government and rural people; to expand the limited representation of traditional authorities at local, provincial and central levels of government; to influence government decisions by embedding information into 
the decision-making process information about the needs, values and aspirations of the traditional communities whom they represent; to attend and participate in workshops for the promotion of traditional authorities and traditional authority areas in order to contribute to the development of the areas concerned, and to ensure that sustainable training is brought to all groups within communities where such training is most needed.

Traditional authorities are traditionally the government institutions closest to the people and should be regarded as such. In this context the framework of the 1996 Constitution should play a pivotal role. This would of necessity require serious consideration of the co-existence of democratically elected rural local government structures and the institution of traditional leadership (RSA, 1998:4.3). The role and position of women should be changed at the request of and in consultation with the rural women concerned. The wishes of rural women themselves should be paramount in this regard. People who are not part of their culture or milieu should not decide on their status and role (RSA, 1998:4.2).

The institution of traditional leadership should be transformed to move with the times. Many traditional leaders accept the role they have to play as part of the new order as well as the resulting challenges associated with the process of transformation. There can be no real rural development in South Africa, during an interim period, without the participation and involvement of traditional authorities as part of local government. It goes without saying that each traditional community should be sufficiently empowered to determine whether they favour the retention of the institution of traditional leadership. It is also accepted that accountability and transparency should characterise all actions undertaken by traditional authorities, and that express provision for the actual implementation thereof be made at the level of each traditional community.

\section{Commonalities and dissimilarities}

\subsection{Commonalities}

The research done in the five regions (the former Lebowa, Venda, Gazankulu (Northern Province), KwaZulu (KwaZulu-Natal) and Bophuthatswana (NorthWest)) has identified a number of commonalities. The broad principles regarding customary law are the same in all the regions. However, the differences existing in the systems adhered to by the various communities are not to be disregarded. It was felt that the traditional authorities should receive training in inter alia the interpretation of customary law and family matters in the light of the Constitution, criminal and civil jurisdiction (in general as well as in the light of the Constitution), the use of natural resources and development management.

All the communities were of the opinion that there should be prior consultation regarding the formulation of policy and legislation which will affect them, the 
Willemien du Plessis

establishment and redefining of traditional community boundaries and the formulation and specification of local government functions vis-à-vis traditional authority functions

Traditional leaders should have civil jurisdiction. Customary land law rules are more or less the same in all the communities. The dispute resolution capacity of traditional authorities should be maintained and strengthened. This statement does not, however, disregard differences that may exist in different communities.

Development functions should be provided for and be discussed with the various communities. According to the traditional communities interviewed, traditional authorities are confident that they can participate in the planning and monitoring of development projects but that they should be given an opportunity to do so with the support and trust of government. Legislation dealing with traditional authorities needs to be rationalised in all the provinces. In each province there are various sections of legislation dealing with the appointment, deposement and functions of traditional leaders. The diverse system of legislation is a legacy of the former "homeland" system.

The appointment and installation of traditional leaders should be in accordance with the wishes of the communities concerned as well as with prevailing custom. Traditional authorities should be a-political in the execution of their functions.

The representation of traditional authorities on the different local government structures is to be renegotiated. Traditional authorities have a role to play at national, provincial and local level.

The provision of services should be the responsibility of local government in consultation with traditional authorities and at the request of the communities concerned. Local government should not prescribe to the communities what their functions should be.

Most communities experience a high crime rate not necessarily emanating from their own communities. Successive governments interfered and abused traditional authorities to meet their own political ends.

Training should be given to traditional authorities and members of the dikgotla as well as the community to understand the implications of the 1996 Constitution. In one province it seems as if negative perceptions exist regarding traditional authorities and as if attempts had been made to curb their authority and recognition. Each province should have a proper policy that is formulated from grassroots level, and in the formulation of policy the communities concerned should play a central role. Empowerment support should be based on communities and other value systems, as well as on perceptions serving as a basis for a sense of security experienced by those who live in traditional 
communities. According to the communities interviewed, decision-makers, policy-makers and law-makers are under an obligation to respect, and not to ignore, this aspect of African culture.

\subsection{Dissimilarities}

More commonalities than dissimilarities were identified in the research done in the five regions mentioned above. In the first place it was clear that communities were in favour of their traditional authorities having civil jurisdiction. However, if proper training was to be given in this regard, they would agree with criminal jurisdiction being accorded to them. There are differences in the allocation of land to unmarried and divorced women and men. Compared to other provinces, more attention has been given by the KwaZulu-Natal legislature (and previously the KwaZulu Legislative Assembly) to traditional authorities by means of legislation. In KwaZulu-Natal the structure of traditional leadership and a monarch protected by statute differs from similar structures in the other provinces

A difference of opinion on the role and position of women within traditional society was encountered. Some women indicated that they were satisfied with their role and position in society. They confirmed that they enjoyed the respect of men and that their views were always taken into account. Others demanded that land should not only be allocated to men but to all women as well, and that women should also be considered for appointment as traditional leaders in all the rural areas comprising South Africa.

\section{Summation of report recommendations}

\subsection{Politico-historical}

The politico-historical research (TARG, 1996f:1-127; 1996k:6-25, 36) indicated that governments should avoid using traditional authorities to achieve their own political ends. In the formulation of policy and legislative measures, there should be respect for traditional authorities and provision should be made for the recognition and protection of the institution of traditional authorities. The payment of traditional authorities should not be used as a tool to manipulate traditional leaders.

\subsection{Legislative perspective}

\subsubsection{Customary law}

A traditional leader is born and is usually the eldest son of the main wife depending on the customary system applicable (cf. TARG, 1996g). With regard to the establishment, identification and termination of the office of traditional authorities from a customary law point of view, it is recommended that the 
hereditary position of traditional authorities be left intact. Communities should be allowed to decide for themselves how their traditional leader should be identified. Section 211 of the 1996 Constitution, however, recognises traditional leadership subject to the Constitution, which, in fact, also subject the institution to fundamental rights. The right to culture (s 30 and 31 ) is also made subject to the Constitution. It leaves the door open to parliament to change the hereditary appointment of traditional leaders.

Regarding the position of councillors and headmen, a form of democratisation can be brought about. The way in which this should be dealt with, should also be decided by the particular community involved. The procedure adopted by the Bafokeng can be taken into account where provision is made for the election of councillors and headmen.

Although the appointment of traditional leaders (who are identified in terms of customary law) may be regarded by some as being against the equality principle, it is not regarded as discrimination by the communities interviewed. During the apartheid era when people other than the hereditary dikgosi were appointed as traditional leaders, it led to dispute and dissatisfaction among the members of the community. It is proposed that effect be given to customary norms pertaining to succession in the case of traditional leadership.

The traditional leaders always played and still have an important role to play in family disputes. If a matter cannot be resolved at family or kgotsana level, it is referred to the traditional leaders. As the traditional leader is seen as the most important and powerful member of the community, as well as the embodiment of all attributes, emotions and values of the community, his or her position in this regard should be respected and recognised. It is stated in the White Paper on Local Government (RSA, 1998:4.2) that the Department of Justice should, in the process of establishing community law courts, take "cognisance of the advantages of customary law courts such as the fact that they are cheap, speedy, informal, conciliatory and accessible". It is also stated that traditional leadership should receive special recognition in the rural community law courts.

The traditional functions regarding family matters differ from community to community. These functions should, however, not be changed without proper prior consultation with the community concerned. The customary family law is regarded as part of the culture of the community. Non-African ideas should not be imposed on communities that do not want them.

Lashes as sentence is regarded as in conflict with the 1996 Constitution (cf. $S v$ Williams and others 19953 SA 632 (CC)). Proper consultation and training should follow (where this has not already been implemented) to bring this to the attention of the various traditional authorities. Alternative forms of sentences should be identified. The Prevention of Family Violence Act 133 of 1993 should 
be brought to the attention of traditional authorities and communities as an alternative recourse. The traditional authorities should be trained to play an important role in the proper application of this Act.

Training should be given to traditional authorities with regard to the possible influence of fundamental rights on customary law, especially in the light of the 1996 Constitution.

The judicial functions vested in traditional authorities should be revisited. Customary judicial functions limited by legislation (e.g. the Black Administration Act 38 of 1927 and the various acts issued by the former "homelands"), may be reinstated or further limited. Not all communities were satisfied with the criminal jurisdiction of the kgotla. The customary and legislative functions given to traditional authorities should be revisited in consultation with the communities concerned. Training should be given to the traditional authorities and members of a kgotla as well as to the community in order to understand and comply with the implications of the 1996 Constitution.

\section{Proposals}

Several general and short term recommendations were made in the report. Possible options to be included in the formulation of policy and possible measures to be included in provincial/national legislation are also proposed (TARG, 1996k:59-73).

\subsection{General and short-term recommendations}

The following general and short-term recommendations were made:

- An interdepartmental steering and policy committee (consisting of relevant national departments such as Constitutional Development, Land Affairs, Agriculture and Justice) should be established as a matter of urgency. This body should formulate and steer policy regarding the role, powers and functions of traditional authorities and determine their relationship with other structures. In addition, empowerment and training programmes must be initiated and implemented. This body should also be empowered to advise national and provincial government at political and administrative levels on the evolving role of traditional authorities. It is also proposed that this interdepartmental committee should be assisted by a technical working group (consisting of academics, NGOs and women rights groups as well as some officials). The main objective would be to do research on behalf of the interdepartmental committee.

- It is questionable whether it is necessary that the president of South Africa be referred to in a statute as the supreme chief of all blacks in South Africa. It is 
recommended that section 1 of the Black Administration Act 38 of 1927 be abolished.

- An accord on the role of traditional leaders in the future development of South Africa should be reached between government, traditional leaders and other role players such as organised local government, to serve as a blueprint for formulating official policy at national, provincial and local government levels on all aspects pertaining to traditional leaders, traditional authorities and customary law. This accord will give rise to a national consensus on which policy, laws and administrative action can be based in future.

- It should be accepted for purposes of policy, law and administrative action in the field of development management, that traditional leadership exists in - terms of a mandate from respective communities functioning within the context of customary decision-making and accountability. This should also be accepted as part of the reality which has to be accommodated in a sociopolitical environment in which there is an obvious need for modern principles of democratic decision-making as contemplated in terms of the RDP and similar policy documents (e.g. GEAR). It is recommended that the provisions of the Development Facilitation Act 67 of 1995 should enable traditional authorities to play a role in the development of the land. As a prerequisite to any development scheme, consultation with the relevant traditional authorities in envisaged areas of development should be laid down in legislation.

- It is strongly recommended that government embark on a judicial, administrative and financial training programme to build capacity among traditional authorities. This can be done inter alia by way of workshops or the establishment of chiefs' schools. Attention should be given to the possibility of forming joint committees on which the local government bodies concerned, as well as the traditional authority for an area, can reach consensus on development projects to be undertaken in that area. This committee could appoint project committees for specific development projects or alternatively, the two bodies concerned could appoint joint project committees comprising of representatives of both the local government body concerned and the responsible traditional authority.

- A comprehensive small-scale mining support system should be established. Such a system will go a long way towards encouraging small-scale operators to co-operate with the state, thereby resolving to some degree the common problem of "illegality" of Small Mining Enterprises (SMEs). The small-scale mining sector should be developed through finance and support of the Small Business Development Corporation (SBDC) or similar funding organisations, which require that the enterprise be run in accordance with sound business practices. The imposition of a small levy on all minerals extracted, based on 
the tonnage removed (depleted), could be considered. Such levies should be low so as not to inordinately raise the investment threshold and should be mineral-specific. Part of the levy could be used to fund past environmental rehabilitation and possibly, mineral promotion organisations. (Cf. also RSA, 1998:4.1: "It must also be acknowledged that there are traditional authorities which have a stake in rich mineral deposits. Through these resources they contribute to development".) The application of a small benefit-related levy on all minerals exported, at a declining rate depending on the degree of beneficiation (zero for the export of metals), could also be considered. Provincial and local government's taxes, levies and surcharges should accord with the principle that mining be taxed on profits

- Regarding the housing policy, special cognisance needs to be taken of the particular characteristics and requirements of rural communities, for example the dilemma facing farm workers reaching the end of their working life or contemplating a change in employment, in terms of the linkage between their employment and home. Regarding rural communities, the following aspects should also be considered: the different composition of rural households; the effects of circulatory migration; the pre-dominance of female-headed households, the non-saleable nature of the rural home; as well as the diversity of tenure arrangements and its impact on especially the accessing of credit and subsidies.

- The involvement of traditional authorities in the implementation of sanitation programmes should be investigated. Traditional authorities should be afforded a place and an opportunity to perform their functions along with those performed by NGOs and local government, within the context of their unique position as important role players in the governance and custodians of the welfare to the people of the various traditional authority areas.

\subsection{Policy proposals}

Various proposals are made that could be included in a policy document on traditional authorities.

\subsubsection{Rural communities and the appointment and dismissal of traditional authorities}

Dikgosi should be installed and recognised according to indigenous law and custom. The same reasoning applies to the deposing of a kgosi. For the purposes of proper administration, the state can confirm this appointment or dismissal. The president/premier must appoint the person indicated by the relevant community. The instalment of dikgosi should be in accordance with the likes of the community in terms of the prevailing custom (cf. also Balatseng \& Du Plessis, 1996:349-355). Regarding the position of councillors and headmen, a 
form of democratisation can be introduced. The way in which this can be dealt with should also be decided by the particular community involved. The provinces can take this into account in the formulation of policy. During the colonial and apartheid era when people other than the hereditary dikgosi were appointed as traditional leaders, it led to dispute and dissatisfaction among the members of the community. It is proposed that in instances such as this the decisions of the communities should be paramount. If a community is divided, the customary mediation principles should prevail. A thorough analysis of developments regarding the content of the institution of traditional leadership over the past few decades indicates the dynamic nature of the institution itself. In this context (giving due consideration to the constitutional provisions regarding democracy), provision should be made for a process which would empower rural communities to decide for themselves what the nature and content of the institution should be - which could in a given case even result in a decision to dispense with the institution.

\subsubsection{Powers and functions}

The powers of traditional authorities according to both custom and legislation are traditionally wide and ill-defined. It would be in the interest of all concerned if the rules regulating the rights and duties of a chief were made more specific and unambiguous.

Poor management practices and poorly planned projects in which the community does not participate, should be prevented. When considering the meaning of development in the context of the role and function of traditional leaders, the concept of development will have to include the full spectrum of development management activities which include development policy, goals and objectives, the implementation of laws reflecting policy principles, management resources and organisational structures, taking care of duties, rights and obligations, accommodating community concerns and needs, being sensitive to natural resource constraints, communication at all levels of development management, promotion of an open, just and transparent process, as well as approaching development (of traditional authority areas) as a people-centred and people-driven process.

In the interests of peace and progress it is important that traditional authorities should remain apolitical in carrying out their functions and that development should not be directly linked to traditional authorities' political affiliations.

\subsubsection{Local government and traditional authorities}

On account of the prevalence of traditional authorities and the extent of their role as provider of services at local (community) level, it is proposed that traditional authorities be ex officio members of local government structures. 
Defining spheres in which traditional and democratic forms of government operate, is of paramount importance in order to clear up the uncertainty which currently prevails.

Traditional authorities are more in touch with community sentiment than the national government. They are therefore valuable links between communities and the state. The state would be wise not to try and abolish their authority or just simply ignore their existence. Existing interests and assets should not be interfered with without proper consultation. These assets, if taken away, should only be used for the betterment of that particular community. Provision should be made for mediation or dispute council or arbitration in the case of disputes (RSA, 1998:4.2).

As traditional authorities are regarded as the government nearest to the people, local government should not interfere with traditional authority land without prior consultation with the relevant authority concerned. Development, if initiated by local government, should only be implemented after proper consultation with the communities concerned.

It is proposed that the number and the representation of traditional authorities in an area where there are more than one such authority, should be properly negotiated with the communities concerned.

In some provinces it seems as if there are negative feelings towards traditional authorities and that attempts are made to curb their authority and recognition. Each province should have a proper policy formulated at grassroots level. In the formulation of the policy, the views of the communities concerned should play a pivotal role.

\subsubsection{Judicial functions}

The dispute resolution capacity of traditional authorities should be maintained and improved. This historical and almost natural ability to deal with dispute resolution is linked to the trust and confidence that people have in their traditional authorities. This trust will only be retained if traditional authorities can function above party politics and by remaining impartial in solving disputes in a consistent, fair and open manner - especially when imposing fines and penalties. This dispute resolution capacity should in future be included in guidelines and legislation made by and for traditional communities.

Corporal punishment is regarded as in conflict with the 1996 Constitution. Proper consultation and training should follow to bring this to the attention of the various traditional authorities. Alternative forms of sentencing should be identified. 
Willemlen du Plessis

\subsubsection{Equality and gender}

An investigation into the role and function of women in traditional society should be initiated. Within this context the constitutional provisions pertaining to equality and the identification of instances of discrimination, disempowerment and hindrances experienced by women, should receive urgent attention. To this end the appointment of a standing committee in which all stakeholders should be represented is imperative. It is of the utmost importance that rural women should represent their own interests. Recommendations of such a committee should be given substance by means of legislation and the adaptation of existing administrative practices. This also entails the reconsideration and elimination of all legislative and administrative measures as well as community values denying women access to positions of power in the traditional community as well as to land.

\subsubsection{Land reform}

The customary land law of each community differs. As is proposed in the White Paper on Land Reform, the land law system of each community should be revisited. Where exploitation or unreasonable discriminatory practices exist, the legal rules should be changed in consultation with the community.

Each community should be given the opportunity to decide whether they want to proceed with the traditional land system or whether they want to revert to another system. It might also be that the community want to grant individual ownership to some parts of communal land, for example in towns. The possible introduction of new tenure forms should, however, be discussed with each community. It is recommended that it is the peoples' right to make decisions about their own tenure systems. In framing new tenure policies, government must actively seek the views of all interested parties, including those who have not been traditionally heard - especially women, the poor and those holding tenuous land rights. Government has a role to play in assisting communities to reconstruct old or develop new forms of communal or group holding in ways that reflect local preferences, on condition that this is undertaken in consultation with the communities concerned. Rights under communal tenure, and the administration of communal tenure systems, must be subject to constitutional fundamental rights provisions, particularly those pertaining to equality, due process and participation. No system of communal tenure should use gender as a basis for the assignment or denial of rights of any kind. The mistrust and suspicion is attributable to the feeling of leaders and community members that they have not been consulted and given the opportunity to discuss among themselves the need for such legislation. It is suggested, on the basis of the Traditional Authority Research Group's research findings, that the Upgrading of Land Tenure Rights Act 112 of 1991 should be implemented only in areas where the communities request the implementation thereof, and once a community 
resolution had been granted to that effect. Which functions a traditional authority should have, should be discussed with the various communities concerned. The functions of local government $v i s-\hat{a}-v i s$ that of the traditional authority, should be clearly spelt out.

\subsubsection{Balanced and sustainable development}

All policy, law and administrative action on the role of traditional leaders in managing development should include the following elements in order to ensure balanced and sustainable development:

- Planning, policy-making and the implementation of development projects should not be a top-down process. All development of traditional authority areas should be approached as a people-driven and community-based process which will in the first instance focus on stability, peace and harmony as the basis for all development activities in rural areas.

- The international experience with regard to rural development and the role and authority of the state should be accepted and included as a policy principle for the development of rural and traditional authority areas. The international experience shows that aside from the establishment of a policy framework and setting and monitoring of national goals, (central) government have a vital supportive function to perform in especially the area of training, the dissemination of information, technical and managerial assistance and a continuous role in the targeted allocation of development finance to achieve public goals.

- Inclusive structures should be put in place to support and promote the right to development as a collective right of members of communities and this right should be balanced by the corresponding responsibility of communities and of government to assist people to realise their potential.

- The issue of land tenure should be separated from the issue of land-use management. Both issues must be addressed in consultation with all role players (including the communities concerned) as part of an inclusive policymaking and planning process.

- Each traditional authority should have the responsibility to pro-actively identify and assist in the planning and monitoring of agricultural, small business, forestry, mining, housing and similar development projects required by the communities to stimulate development and to create new development opportunities in traditional authority areas.

- Traditional authorities should be sensitised to their responsibilities as important roleplayers in respect of development and they should be equipped and supported in this task by government. Any land development to be 
undertaken for traditional authority areas should be preceded by proper consultation involving all sectors of the affected community, including the private sector, aimed at achieving optimal participation in the development process. The Development Facilitation Act 67 of 1995 should also be implemented by traditional authorities. It is recommended that local government, through elected representatives, embarks on a needs assessment programme of the needs of the traditional authorities. Government must, in consultation with the relevant directorate in the Constitutional Development Department, initiate a programme for the dissemination of information on subsidies. Development must be a joint venture undertaken by traditional authorities and local government bodies in terms of the common goals and objectives, ensuring a common understanding of the needs of the community - and ensuring that both remain accountable to the communities in the traditional authority areas.

- It is recommended that on all levels provision be made in government budgets for funds to be allocated for the proper administration of traditional authority areas by traditional authority offices. Where misuse of power by traditional leaders take place, these occurrences should be addressed and, where available remedies are not sufficient, suitable ways in addressing wrongs must be developed.

\subsubsection{Administrative structures}

Traditional authority offices should be developed to become fully fledged administrative centres for the purposes of implementing development policy, laws and for the dissemination of information, as well as the keeping records for and on behalf of government institutions. This should be done in such a manner that these offices can assist the local government concerned in carrying out service delivery and development functions.

\subsubsection{Budget and finance}

Government must, on a continuous basis, make provision in its budget for training in accordance with the needs of traditional authorities and their committees as new training needs arise. A compulsory strategic planning process should be undertaken by traditional authorities before any budget or financial assistance may be applied for. Training and strategic financial planning can be integrated to ensure a hands-on approach to this aspect of empowerment. Performance-based allocation of resources in accordance with development criteria and predetermined development goals should be introduced. Mechanisms and procedures should be introduced that will grant access for local authorities and traditional authorities (and the traditional communities they service) to development project funding. Subsequently development project funding will, in the short term, establish tangible development in which poor 
communities can participate through community or village committees and which will help to create job opportunities in the rural areas. Equitable regional allocation of development resources should be introduced. The limited national resources available to support the provision of basic services should be equitably distributed among regions, taking account of the population and level of development.

\subsubsection{Training}

Training programmes should be made available to traditional authorities, focusing on inter alia the possible influence of fundamental rights on customary law, especially in the light of the 1996 Constitution. Voluntary training should be available to members of the kgotla regarding both constitutional matters and customary law. The dikgosi should be given training to understand the constitutional implications of family law matters. The education, training and orientation of traditional leaders enabling them to operate in accordance with accepted democratic values, specifically with regard to their role in development planning and the implementation of development programmes or projects are needed. Appropriate leadership training in all aspects of modern development management should be undertaken.

Separate community-based training of traditional authority members jointly with members representing various sectors of community life, is a necessity (where policy and laws can only be implemented by traditional authorities) so as to ensure adequate training in situational management and hands-on education on land use and environment, with the assistance of residents of traditional authority areas.

A separate government department for supporting traditional authorities in the execution of their functions, also in respect of development management functions should be established. The dissemination of information aimed at marketing the concept of traditional authorities and their role in rural social life, should be undertaken to educate the broader public. In this way a more balanced idea and perception of traditional authorities will be created.

The value of this link, as well as the most advantageous ways of making use of this in the process of governance, must be well understood by government and should be included in civil servants' training as part of the process cultivating an awareness among government and traditional authorities of the responsibilities of each sector. It is strongly recommended that government should embark on a judicial, administrative and financial training programme to build capacity among traditional authorities. This can be done inter alia by way of workshops or the establishment of chiefs' schools. Illiteracy among traditional authorities should be addressed by the government through making provision for the coopting of villagers who are literate to assist traditional authorities who are 
illiterate. It is felt that this problem will eventually disappear, but in the meantime it can assist in providing jobs to educated rural villagers.

\subsubsection{Consultation}

The traditional functions regarding family matters differ from community to community. It should not be changed without proper prior consultation with the community concerned. Family law is regarded as part of the culture of the community. Non-African ideas should not be imposed on communities that do not want it.

Compulsory seminars and consultation sessions involving traditional authorities and government officials from provincial and local government should be organised, at which occasions practical development related matters are discussed and solutions to problems are formulated. The dynamics of, needs for, and advantages of accommodating and liaison with traditional authorities, shall be part of civil service training at all levels of government. Consultation between government and traditional authorities on all matters in respect of which laws and regulations are to be made, and especially when amending custom and customary law by way of new legislation, is anticipated.

\subsubsection{Contribution of traditional authorities in related policies and policy formulation}

Traditional authorities should be afforded a place and an opportunity to be involved in the implementation of water and sanitation programmes. They should perform functions similar to those of NGOs within the context of their unique position as being part of the de facto rural governance structures and custodian of the welfare of the communities residing in the various traditional authority areas. The policy may include a labour-based approach, capacity building, education and training, relation of the policy to the housing policy and the environmental policy.

The impact of different sanitation options must be weighed against the impact of unimproved sanitation practices. Traditional authorities could act as a link with government departments to ensure sound administration of subsidies and funds made available for water and sanitation projects.

Detailed policy issues should include land (and resource) use and administration; issues need to be addressed clearly by environmental, forest, water, rural land development policy and law, particularly in regard to the links between tenure and participative planning and management; land tenure policies should include long-term, inheritable tenure in communal land, as well as redistributed land, tenure being part of the larger spectrum of land and resource administration. 
The value of participative management in enhancing the prospects for such aspects of the natural environment as woodland conservation and management through the inclusion of detailed reference to and meeting of local needs, and maintaining or restoring the sense of ownership among communities, should be recognised.

A framework (including the legislative framework) could be developed for customary, community-based and state institutions to operate and derive benefits from the management of resources as well as the development of management and planning capacity within such local institutions, especially when the old arrangements have collapsed under pressure of demography and political forces built upon existing natural resource management institutions.

Strategies for extension services should explicitly be focused on enhancing and building on existing practices. Particular attention needs to be given to rendering the benefits of areas protected for the preservation of biological diversity apparent and real to neighbouring communities. In areas where forests and woodlands exist or could be established, the setting, applying and monitoring of sustainable harvesting of forest and woodland products such as timber, fuelwood and non-timber forest products such as fruit, game and medicinal products are necessities. Forest policy should at least ensure the evaluation of product pricing, especially the products for use or consumption beyond the community or land owner.

The potential for forestry to contribute to environmental improvement through replanting of irreversibly degraded land and rehabilitated mine land, as well as for the mitigation of acid-mine drainage through increasing evaporation should be investigated.

The need for educating and informing farmers and other land users and managers and communities about policies, options, and procedures for managing natural forests and woodlands is imperative.

\subsubsection{Policy implementation}

It can be concluded that on issues relating to the implementation of policy, the role of traditional authorities be recognised only where the existence of such authorities is historically proven. Any decision-making power should be restricted solely to areas of indigenous and customary law. Decision-making must never be in conflict with the constitution or laws and regulations at national, provincial and local levels. Practical formal structures should be set to ensure harmonious co-operation between traditional authorities and all spheres of government. 


\subsubsection{New legislation}

New legislation regarding traditional authorities should only be drafted with the active involvement and participation of the affected communities. The legislation pertaining to traditional authorities in the different provinces should be rationalised and be negotiated at grassroots level.

Any new provincial legislation should reflect what communities themselves want; the diversity of cultural systems within the province (especially in the Northern Province); the possibility to divert from specific legislation in by-laws, as long as the by-laws are reconcilable with the enabling legislation, the functions of the traditional authorities vis-à-vis the local authorities, the importance of consultation between traditional authorities and local government for the provision of services in the traditional areas; the importance of arbitration in cases of conflict between the local authority and the traditional authority or members of the communities themselves, as well as the position of the dikgosi.

Traditional leaders should also be consulted in the drafting process of laws or any other guidelines. They should also be involved in the planning as well as the implementation phase of development projects for their areas.

\subsection{Legislative proposals}

The following may be included in legislation. It must, however, be stated that legislation can only be drafted subsequent to a proper consultation process with all the communities concerned, taking into account their views at grassroots level.

\subsubsection{Broad principles}

The following broad principles to be included in the Act, should be discussed with the various communities concerned: democracy (constitutional and African democracy); equality; sustainable development; reconstruction and development; transparency; accountability; Ubuntu; consultation and participation, as well as capacity-building and training.

\subsubsection{Recognition of the institution of traditional leadership}

A probable formulation of a clause in national legislation dealing with the institution of traditional leadership may be the following (TARG, 1996k:68-69):

1. The institution, status and role of traditional leadership, according to indigenous and customary law are hereby recognised subject to the constitution.

2. The appointment of traditional leaders according to the laws and customs of the community concerned shall be formally confirmed by the President or the Premier of the relevant province as provided for in national legislation. 
3. The withdrawal of the appointment of traditional leaders according to the laws and customs of the community concerned shall likewise be formally confirmed as provided for in subsection (2).

4. The national legislation referred to in subsection (2) in this regard shall only be enacted and national policy guidelines be issued in terms of such legislation after having complied with a process of consultation with all the traditional leaders and their communities concerned as prescribed by national legislation.

Regarding the position of councillors and headmen, a form of democratisation should be introduced. The way in which this can be dealt with, should also be decided by the particular community involved. The various provinces should take this into account in the formulation of policy. The establishment of separate communities and the alteration of boundaries should also only be done in consultation with the communities concerned.

\subsubsection{Role of traditional leadership at national level}

The National House of Traditional Leaders should continue to exist.

\subsubsection{Role of traditional leadership at provincial level}

The Provincial Houses of Traditional Leaders should continue to exist. Their advice on customary law or matters affecting customary communities should be taken seriously. The same clause as discussed above at the National House of Traditional Leaders, should be taken into account. The Houses must, however, be allocated a sufficient budget in order to fulfil their role as set out by the Provincial Houses of Traditional Leaders Acts.

\subsubsection{Role of traditional leadership at local level}

It is still an open debate what the actual role of traditional leaders at local level should be. National or provincial legislation may include the following clause (TARG, 1996k:71-72):

1. The legislature of each province in which there are traditional authorities and their communities shall promulgate legislation to ensure sufficient representation of traditional leaders or their representatives in local government, district or nural government structures.

2. In districts and areas in provinces demarcated for the purposes of local government administration and where two or more traditional authorities exist, representative forums for traditional authorities shall be established by way of provincial legislation.

3. The purpose of the forums shall be to make recommendations and to advise local government, district or rural councils with regard to any by-laws, proposed by-laws, proposed policy, planning and decision-making which 
may affect traditional authorities and their communities, indigenous and customary law.

4. The forums may of their own accord and shall at the request of the local government, district or rural council, advise local government, district or rural councils on any matter falling within the scope of the terms of reference as prescribed by this Act and provincial legislation.

5. Should the local government, district and rural council decide not to follow the advice of the relevant forum referred to in subsection (4), it must enter into a process of negotiation with the forum until sufficient consensus is reached.

6. The composition and powers of the forums shall be regulated by provincial legislation. The powers of the forums shall include the power to monitor; to investigate and to report on the observance of the status and role of the institution of traditional leadership and indigenous and customary law; to take steps to secure appropriate redress where traditional authorities, the indigenous law, or the traditions and customs have been violated; to carry out research and to implement appropriate education programmes dealing with the application and development of the institution of traditional leadership and indigenous and customary law

7. The forums shall have the additional powers and functions prescribed by provincial legislation.

8. The provincial legislation referred to in subsection (6) regarding the composition and powers of the forum shall only be enacted after having complied with a process of consultation with all the traditional authorities and their communities concerned prescribed national legislation.

\subsubsection{Functions}

The following functions should be allocated to traditional authorities in provincial or national legislation. A traditional leader looks after the interests and well-being of his or her community. He or she should exercise the functions in terms of prevailing custom. In the case of judicial customs, he or she should have civil jurisdiction and/or criminal jurisdiction depending on the wishes of the community. In the case of procedural matters the kgotla should be a court of record. Rules of evidence should be interpreted in the light of the Constitution. The aim of the customary courts is reconciliation. Legal representation should be allowed. The imposition of fines and levies should be done in a just, fair and non-arbitrary manner in accordance with the principles of consultation, community participation and transparency.

The development functions of traditional authorities should be described $v i s-a-$ vis local government. Their role in land development administration should be set out as well as their role in the implementation of related policies. The traditional authorities' relationship with the Development Facilitation Act and other land legislation should be spelt out clearly.

Koers 64(2 \& 3) 1999:295-324 
Traditional authorities should be allowed to issue by-laws in respect of issues as determined by the community, that are not in conflict with the Constitution, provincial and local government legislation. They should be able to regulate and collect taxes, levies and revenue and to impose fines.

\subsubsection{Traditional monarchy}

Provisions should be formulated by means of provincial legislation in respect of the relevant provinces

\subsubsection{Organs of state}

Traditional authorities should be defined as organs of state for the purposes of financial matters, judicial matters and their administrative functions.

\subsubsection{Consultation}

As a prerequisite to any development scheme, formulation of policy and legislation, consultation with the relevant traditional authorities and all relevant sections of the communities should take place.

Any land development to be undertaken for traditional authority areas should be preceded by proper consultation involving all sectors of the affected community, including the private sector, aimed at achieving optimal participation in the development process.

\subsubsection{Indigenous Communities Commission}

The creation of an Indigenous Communities Commission and an Indigenous Communities Court to advise and adjudicate disputes regarding the identity, independence or membership of the community, the functions of the leaders and other governance organs of a traditional community, succession to leadership, discipline against a leader or any other institution in the community, is recommended

\subsubsection{Access to development project funding}

Traditional authorities should have access to development project funding.

\section{Conclusion}

Traditional leaders are recognised by their communities as inter alia the upholder of values. In some instances it is said that they derive their authority from God. Traditional authorities are recognised both in terms of the Constitution and by their communities. They have a definite role to play in the development of South Africa. Although, at first glance, the institution of traditional authorities is seen as in conflict with democracy, it is according to 
some, regarded from an African perspective, as to fully comply with African democracy. According to this view, African democracy is in some instances regarded to be more "democratic" than Western democracy. In African tradition no decision will probably be made if consensus is not reached.

Various proposals have been made regarding the future role of traditional authorities. These proposals include that government should avoid using traditional authorities to achieve its own political ends. Communities should be allowed to decide on the content and future of the institution of traditional leadership in their area.

Legislation pertaining to traditional authorities should be rationalised in the different provinces in consultation with all the relevant stakeholders (including the traditional communities themselves). Legislation should be introduced at national and provincial level to establish structures to ensure the continuation of the institution of traditional leadership and to facilitate the participation by communities in the formulation of legislation and policy pertaining to the institution of traditional leadership, customary law and matters affecting rural communities.

Structures should be established to delineate local level powers and functions between democratically elected local government bodies and traditional authorities

The role and status of women and the youth in traditional societies should be investigated, having regard to the views of the rural women themselves. Various training programmes and the necessary infrastructural support should be made available to traditional authorities. Traditional authorities and their communities should play a meaningful role in the development of their areas.

An interdepartmental steering committee (consisting of relevant national departments) should be established as a matter of urgency with a view to the formulation of policy and the establishment of sufficient liaison with other levels of government. An accord on the role of traditional leaders in the future development of South Africa should be reached between government, traditional leaders and other role players.

The planning, implementation and management of development should closely involve traditional communities and their leaders. The principle of accountability of traditional authorities towards the communities as well as to structures of government, should be entrenched.

Only if the role that traditional authorities should play as regards development planning and implementation is formally determined, real development will take place in the rural areas. If the role of traditional authorities is not spelt out, the 
development process and the implementation of GEAR will not happen in an efficient and effective manner.

To ensure proper participation and a co-operative government, the law has a vital role to play - on the one hand to ensure that traditional communities are protected but on the other hand to protect and enhance the role of vulnerable groups such as women and children within the traditional framework.

\section{Bibliography}

ANON. 1998a. Amakhosi moet groter rol kry in plaaslike regering. Beeld: 6, March 18

ANON. 1998b. Buthelezi sê ANC in KZN wil amakhosi vernietig; prys Mbeki. Beeld. 14, Mei 23

ANON. 1998c. Amakhosi in KZN verwerp witskrif oor dié regering. Beeld. 6, Mei 25.

BALATSENG, D. \& DU PLESSIS,W. 1996. Succession of chieftaincy: hereditary, by appointment or by common consent? - Chief Pilane v Chief Linchwe 19954 SA 686 (R). Tydskrif vir Hedendaags Romeins-Hollandse Reg, (2):349-355.

REPUBLIC OF SOUTH AFRICA. 1998. White Paper on Local Government. Government Notice 423. Government Gazette 18739, March 13. RSA

see REPUBLIC OF SOUTH AFRICA.

TARG see TRADITIONAL AUTHORITIES RESEARCH GROUP

TRADITIONAL AUTHORITIES RESEARCH GROUP. 1996a. The administrative and legal position of Traditional Authorities in South Africa and their contribution to the implementation of the Reconstruction and Development Programme. Volume I - Project Background. (Unpublished.)

TRADITIONAL AUTHORITIES RESEARCH GROUP. 1996b. The administrative and legal position of Traditional Authorities in South Africa and their contribution to the implementation of the Reconstruction and Development Programme. Volume II Theoretical framework. (Unpublished.)

TRADITIONAL AUTHORITIES RESEARCH GROUP. 1996c. The administrative and legal position of Traditional Authorities in South Africa and their contribution to the implementation of the Reconstruction and Development Programme. Volume III Northern Province. (Unpublished.)

TRADITIONAL AUTHORITIES RESEARCH GROUP. 1996d. The administrative and legal position of Traditional Authorities in South Africa and their contribution to the implementation of the Reconstruction and Development Programme. Volume IV KwaZulu-Natal Province. (Unpublished.)

TRADITIONAL AUTHORITIES RESEARCH GROUP. 1996e. The administrative and legal position of Traditional Authorities in South Africa and their contribution to the implementation of the Reconstruction and Development Programme. Volume V - North West. (Unpublished.)

TRADITIONAL AUTHORITIES RESEARCH GROUP. 1996f. The administrative and legal position of Traditional Authorities in South Africa and their contribution to the implementation of the Reconstruction and Development Programme. Volume VI Politico-historical background. (Unpublished.)

TRADITIONAL AUTHORITIES RESEARCH GROUP 1996g. The administrative and legal position of Traditional Authorities in South Africa and their contribution to the implementation of the Reconstruction and Development Programme. Volume VII - Legal report. (Unpublished.) 
TRADITIONAL AUTHORITIES RESEARCH GROUP. 1996h. The administrative and legal position of Traditional Authorities in South Africa and their contribution to the implementation of the Reconstruction and Development Programme. Volume VIII Development management. (Unpublished.)

TRADITIONAL AUTHORITIES RESEARCH GROUP. 1996i. The administrative and legal position of Traditional Authorities in South Africa and their contribution to the implementation of the Reconstruction and Development Programme. Volume IX Constitutional proposals. (Unpublished.)

TRADITIONAL AUTHORITIES RESEARCH GROUP. 1996j. The administrative and legal position of Traditional Authorities in South Africa and their contribution to the implementation of the Reconstruction and Development Programme. Volume X Conference proceedings. (Unpublished.)

TRADITIONAL AUTHORITIES RESEARCH GROUP. 1996k. The administrative and legal position of Traditional Authorities in South Africa and their contribution to the implementation of the Reconstruction and Development Programme. Volume XI Overview report. (Unpublished.)

TRADITIONAL AUTHORITIES RESEARCH GROUP. 19961. The administrative and legal position of Traditional Authorities in South Africa and their contribution to the implementation of the Reconstruction and Development Programme Volume XII Integrated bibliography. (Unpublished.)

TRADITIONAL AUTHORITIES RESEARCH GROUP. 1996m. The administrative and legal position of Traditional Authorities in South Africa and their contribution to the implementation of the Reconstruction and Development Programme. Volume XIII Annexures. (Unpublished.)

TRADITIONAL AUTHORITIES RESEARCH GROUP. 1996n. The administrative and legal position of Traditional Authorities in South Africa and their contribution to the implementation of the Reconstruction and Development Programme. Volume XIV Executive summary. (Unpublished.)

VAN DER VYVER, J.D. 1975. Die beskerming van menseregte in Suid-Afrika. Kaapstad Juta.

\section{Legislation}

Black Administration Act 38 of 1927.

Constitution of the Republic of South Africa 200 of 1993

Constitution of the Republic of South Africa 108 of 1996.

Development Facilitation Act 67 of 1995.

Local Government: Municipalities Structures Act 117 of 1998

Prevention of Family Violence Act 133 of 1993

Upgrading of Land Tenure Rights Act 112 of 1991.

\section{Court decisions}

$S v$ Williams and others 19953 SA 632 (CC). 


\section{Traditional Authorities Research Group}

(See title page of this article.)

The members of the team responsible for the research underlying this article are the following - in alphabetical order: D. Balatseng (University of the North West), J. Chiumya (University of the North); B. de Wet (University of the North); W. du Plessis (PU for CHE); G. Ferreira (PU for CHE); L. Jansen van Rensburg (PU for CHE); S. Luthuli (University of Zululand); M. Mabiletsa (University of the North); K. Mojela (University of the North); P. Mtsaulana (Legal Resources Centre); R. Ndou (Department of Constitutional Development \& Provincial Affairs); S. Nzimande (University of Zululand); N. Olivier (University of Natal - Pietermaritzburg, presently Department of Constitutional Development \& Provincial Affairs - University of Pretoria); B. Oomen (Van Vollenhoven Institute for Law in Non-Western Countries - University of Leiden Netherlands); J.M. Otto (Van Vollenhoven Institute for Law in Non-Western Countries - University of Leiden Netherlands); C. Rautenbach (PU for CHE); D. Selala (University of the North West); T.E. Scheepers (PU for CHE); J.A. van den Heever (University of the North); A.C. van der Walt (PU for CHE); J. Williams (University of Natal - presently attorney at Berkow, Feinberg \& Suliman Inc, Pretoria). The report consists of 14 volumes and is known as the Traditional Authorities Research Group The administrative and legal position of Traditional Authorities in South Africa and their contribution to the implementation of the Reconstruction and Development Programme (1996). 